\title{
Review Article \\ Comparative Study of Maximum Power Point Tracking Techniques for Photovoltaic Systems
}

\author{
Fernando Lessa Tofoli, Dênis de Castro Pereira, and Wesley Josias de Paula \\ Department of Electrical Engineering, Federal University of São João del-Rei, Praça Frei Orlando, 170 Centro, \\ 36307-52 São João del-Rei, MG, Brazil \\ Correspondence should be addressed to Fernando Lessa Tofoli; fernandolessa@ufsj.edu.br
}

Received 20 November 2014; Revised 12 January 2015; Accepted 19 January 2015

Academic Editor: Wayne A. Anderson

Copyright (C) 2015 Fernando Lessa Tofoli et al. This is an open access article distributed under the Creative Commons Attribution License, which permits unrestricted use, distribution, and reproduction in any medium, provided the original work is properly cited.

\begin{abstract}
The generation of electricity from photovoltaic (PV) arrays has been increasingly considered as a prominent alternative to fossil fuels. However, the conversion efficiency is typically low and the initial cost is still appreciable. A required feature of a PV system is the ability to track the maximum power point (MPP) of the PV array. Besides, MPP tracking (MPPT) is desirable in both gridconnected and stand-alone photovoltaic systems because the solar irradiance and temperature change throughout the day, as well as along seasons and geographical conditions, also leading to the modification of the $I \times V$ (current versus voltage) and $P \times V$ (power versus voltage) curves of the PV module. MPPT is also justified by the relatively high cost of the energy generated by PV systems if compared with other sources. Since there are various MPPT approaches available in the literature, this work presents a comparative study among four popular techniques, which are the fixed duty cycle method, constant voltage (CV), perturb and observe (P\&O), and incremental conductance (IC). It considers different operational climatic conditions (i.e., irradiance and temperature), since the MPP is nonlinear with the environment status. PSIM software is used to validate the assumptions, while relevant results are discussed in detail.
\end{abstract}

\section{Introduction}

In the next few years, the world is supposed to face several problems related to the exhaustion of some energy sources, mainly those regarding fossil fuels. It is also well known that some aspects concerning the increase of oil price due to economic and political questions have been the cause of economic crisis in the last decades [1]. The search for renewable energy sources then becomes more and more intense as a prominent alternative for the mitigation of the world energy crisis.

Among the clean and green power sources, the photovoltaic (PV) solar energy comes up as an interesting alternative to supplement the generation of electricity [2]. The significant cost reduction of PV modules in the last few years has made the use of solar energy particularly attractive, mainly in small single-phase residential systems connected to the utility grid and stand-alone applications [3].

Electric energy can be obtained through direct conversion of light into electricity, which consists in the photovoltaic effect. Besides, solar energy is free for use, abundant in nature, and nonpolluting and has a fundamental role regarding the existence of all primary energy sources on Earth $[4,5]$.

Despite all the aforementioned advantages, the conversion efficiency is low and the initial cost is still appreciable, as it is necessary to use MPPT techniques in order to maximize the extracted energy. It is important to emphasize that there is only one MPP for each curve at given temperature and irradiance levels.

Within this context, this paper presents the performance comparison among four MPPT techniques widely known in the literature by using a dc-dc buck-boost converter operating in continuous conduction mode to supply a given load. For this purpose, the methods are implemented and evaluated in software PSIM. The specific scope of this work comprehends the following issues:

(i) brief description of PV modules;

(ii) implementation of four MPPT techniques in PSIM, which are fixed duty cycle, $\mathrm{CV}, \mathrm{P} \& \mathrm{O}$, and IC; 
(iii) performance analysis of a dc-dc converter acting as a MPP tracker.

\section{MPPT Techniques}

2.1. Brief Literature Review. Although the scope of this paper comprises only a comparison among the aforementioned techniques, several papers on MPPT are available in literature, while some of them are briefly described as follows to demonstrate the relevance of this topic.

Enslin and Snyman [6] present a simplified control technique based on the positive feedback effect of the output current regarding low-power MPPT converters. The characterization and behavior of the PV module and the efficiency analysis of the system are also discussed in this work [6].

Sullivan and Powers [7] present a MPPT technique considering a PV system used to supply electric racing cars. The experimental vehicle has six PV modules divided in nine sections; each one is connected separately to a MPP tracker and the output links are parallel-connected in order to recharge the battery [7].

Hua and Shen [8] analyze the performance of dc-dc converters using P\&O in PV systems. This choice is justified considering the reduced number of sensors and the global complexity of the PV system [8].

Ibrahim et al. [9] introduce a pumping system powered by PV arrays connected to a buck converter acting as a MPP tracker. The output voltage is measured and compared to the open circuit voltage in a look-up table, so that a relationship among these values can be established in order to obtain the exact voltage across the PV module [9]. Adnene and Moncef [10] use the same comparison principle in pumping systems to obtain a satisfactory result on the output voltage considering the dynamic model of the PV system composed by the association of a dc-dc converter, an inverter, and an asynchronous motor [10].

Similarly, Hohm and Ropp [11] propose an algorithm based on the measurement of the open circuit voltage. It considers that the operating point is close to the MPP when the voltage across the PV module is about $76 \%$ of the open circuit voltage [11].

Hsiao and Chen [12] present a MPPT algorithm which is called three-point comparison method. The ripple around the MPP is analyzed by comparing three points of the power curve. Since P\&O uses only two points of the power curve to track the MPP, the work is based on a point by point analysis [12].

Huang et al. [13] present an experimental comparison of techniques regarding the efficiency of some MPPT algorithms. It is shown that $\mathrm{P} \& \mathrm{O}$ is the most common algorithm used in commercial converters. IC has a performance level close to $\mathrm{P} \& \mathrm{O}$, but in general the higher implementation cost compared to $\mathrm{P} \& \mathrm{O}$ would not be justified by an improvement in performance [13].

Esram and Chapman [14] focus on various MPPT techniques from the analysis of more than 90 compiled papers. Methods such as $\mathrm{P} \& \mathrm{O}$ and hill climbing (HC) are found to be of simple implementation in either analog or digital forms. On the other hand, IC is slightly more complex and requires digital circuitry. However, the choice of a given method depends on engineers' and designers' knowledge and familiarity with analog and digital circuitry [14].

Nordin and Omar [15] validate generic and user-friendly PV array and MPPT models based on mathematical expressions and a circuit approach. The PV array model uses the irradiance and temperature as the input parameters and provides the corresponding characteristic curves. $\mathrm{HC}$ is also implemented to track the MPP [15].

Rani et al. [16] study how the partial shading of PV modules affects the MPPT. The output power of PV arrays decreases significantly when one or more cells/modules are shaded. Partial shading can be caused by buildings, trees, and poles. In large PV systems, moving clouds may also lead to partial shading, which changes the PV characteristics with multiple peaks, apart from reducing the energy extraction from PV systems. The occurrence of such multiple peaks can mislead some MPPT algorithms to get trapped at local peaks [16].

The connection of PV cells and modules in parallel in order to avoid the effect of partial shading is an interesting solution, even though it is restricted to low and medium power applications due to the number of converters and components that may be necessary to increase power [17]. Distributed MPPT (DMPPT) is used by Koutroulis and Blaabjerg [17], where a $\mathrm{dc}$-dc power converter with MPPT controller is incorporated to each PV module of the string, thus increasing the total available power of the array [17].

Fakhfakh et al. [18] propose a control technique applied to a grid-connected PV system. The proposed approach includes a PV module, a dc-dc converter, and a dc-ac converter. MPPT is performed by the dc-dc converter, while hysteresis control technique is used to drive the dc-ac converter [18].

Sahu et al. [19] present the estimation of the MPP in a PV array under different environmental conditions (i.e., temperature and solar irradiation) using Levenberg-Marquardt method. The estimation uses the single-diode-based model of the PV module and the related parameters are obtained from the datasheet provided by the manufacturer [19].

As it was mentioned before, numerous approaches have been proposed to achieve MPPT in PV systems. However, few works are dedicated to the performance comparison of existing techniques and this issue is supposed to be analyzed as follows.

2.2. Description of Some MPPT Techniques. A PV system is typically composed of a PV array, an intermediate dc-dc stage, and a dc-ac converter that allows obtaining ac voltages in either grid-connected or stand-alone applications. The dc-dc converter plays an important role not only in the voltage stepup of the PV modules, but also in the achievement of the MPP. Literature presents numerous examples of power converter topologies adequate for this purpose, for example, the dc-dc interleaved boost converter for high power applications [20].

The PV module generates a dc current which depends on the intensity of solar irradiance and room temperature. The power produced by a PV module corresponds to a value measured in watt-peak (Wp). The standard test conditions (STC) allow defining the power capacity corresponding to a solar irradiance level of $1000 \mathrm{~W} / \mathrm{m}^{2}$ and room temperature of $25^{\circ} \mathrm{C}$. 


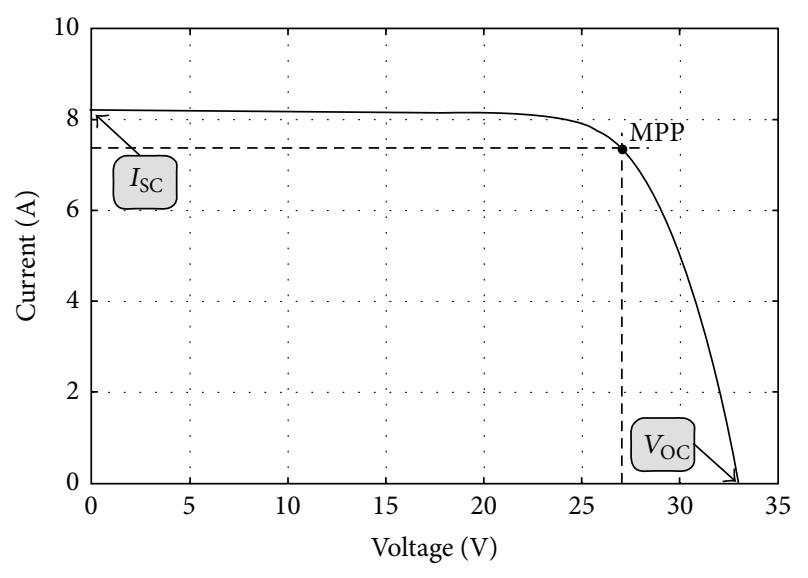

Figure 1: $I \times V$ curve.

Typically, parameters such as the short-circuit current, open circuit voltage, and MPP ratings are measured under STC and provided by manufacturers in datasheets. The PV module is typically connected to an MPP tracker in order to optimize the extracted dc power, which varies with both temperature and irradiance levels. The dc power then is converted to ac power by using an inverter stage that can be connected to the power grid or supply a given load directly [15].

The characteristic curve of a PV module is defined according to temperature and irradiance conditions. The maximum power $P_{\max }$ is achieved by the product of the maximum power voltage $\left(V_{\max }\right)$ and the maximum power current $\left(I_{\max }\right)$ in the $I \times V$ curve, that is,

$$
P_{\max }=V_{\max } \cdot I_{\max } \cdot
$$

Figure 1 presents the $I \times V$ curve of a PV cell, where three important parameters can be identified:

(i) short-circuit current $\left(I_{\mathrm{SC}}\right)$ : current that flows through an illuminated cell when the voltage across it is null (short-circuit condition);

(ii) open circuit voltage $\left(V_{\mathrm{OC}}\right)$ : voltage across an illuminated cell when the flowing current is null (open circuit condition);

(iii) MPP: point of the $I \times V$ curve whose product between the voltage and current is maximum.

The variation of solar irradiance has great influence on the maximum power current, while it does not affect considerably the maximum power voltage. The temperature variation has an opposite behavior, with great influence on the maximum power voltage.

For a given operating condition, the MPPT algorithm can provide a current reference (CMPPT) or a voltage reference (VMPPT) to the converter controller operating in closed loop. The reference provided by the MPPT block represents the position of the MPP. Another possible configuration is the direct duty cycle control, where the MPPT acts directly on the turn on and turn off of the controlled switch [21]. However, the latter technique subjects the converter to excessive stress and increased losses [22].

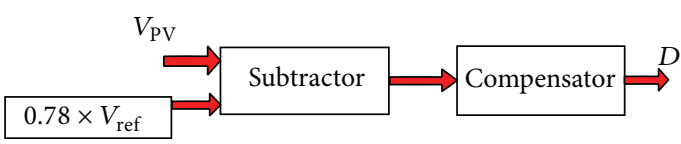

FIgURE 2: Flowchart of the CV technique.

The choice between the voltage and current to track the MPP is thoroughly discussed in literature [4, 23-26]. According to [23], due to the fact that the PV array voltage remains relatively constant over a wide range of the solar radiation, the choice of voltage control is better recommended. The author in [24] says that the current through the PV array varies strongly with the radiation. And yet, the transient responses of the MPPT algorithm may cause the saturation of the PV array at short-circuit condition, resulting in a sudden drop in voltage and extracted power $[24,25]$. However, the work developed in [4] proposes the control of the PV array current and concludes that it is more advantageous compared to the voltage control using the IC method. The aforementioned works have in common the analysis of each method through assumptions made based only on the characteristic curves of PV panels.

Several MPPT techniques have been considered in literature and can be classified as either off-line or on-line techniques. Off-line techniques demand the accurate positioning of the PV array associated with temperature and irradiance measurements. On the other hand, such measurements are not used in on-line techniques, which are more efficient than their counterparts regarding stability, dynamic response, steady-state error, robustness, and performance, when great variations of the extracted power are considered. Some important MPPT techniques are briefly described as follows.

2.2.1. Fixed Duty Cycle. The fixed duty cycle method represents the simplest MPPT approach, since it does not need any feedback signal and the apparent load resistance is adjusted only once in order to extract the maximum power from the module, being classified as an off-line technique. This method is functional, but not efficient. By disregarding the variation of the maximum power voltage, which is due to the temperature and the solar irradiance, this method aggregates appreciable error to the extracted power profile. Besides, this method is firstly implemented in order to define if an on-line technique is necessary to improve the PV system performance significantly.

2.2.2. Constant Voltage ( $C V)$. The constant voltage technique uses empirical results to show that the MPP voltage is about $70 \%$ to $80 \%$ of the open circuit voltage across the PV module under STC $\left(1000 \mathrm{~W} / \mathrm{m}^{2}, 25^{\circ} \mathrm{C}\right)$. Among the various MPP points for varying atmospheric conditions, the voltage across the PV module does not vary significantly, even when irradiance effectively does. Thus, by ensuring that the voltage across the module remains constant, it is possible to operate close to the MPP. This can be achieved by using a voltage loop according to Figure 2 . This method demands only one voltage sensor $\left(V_{\mathrm{PV}}\right)$. In analog implementations, the voltage across the PV module is measured by a voltage sensor and compared 


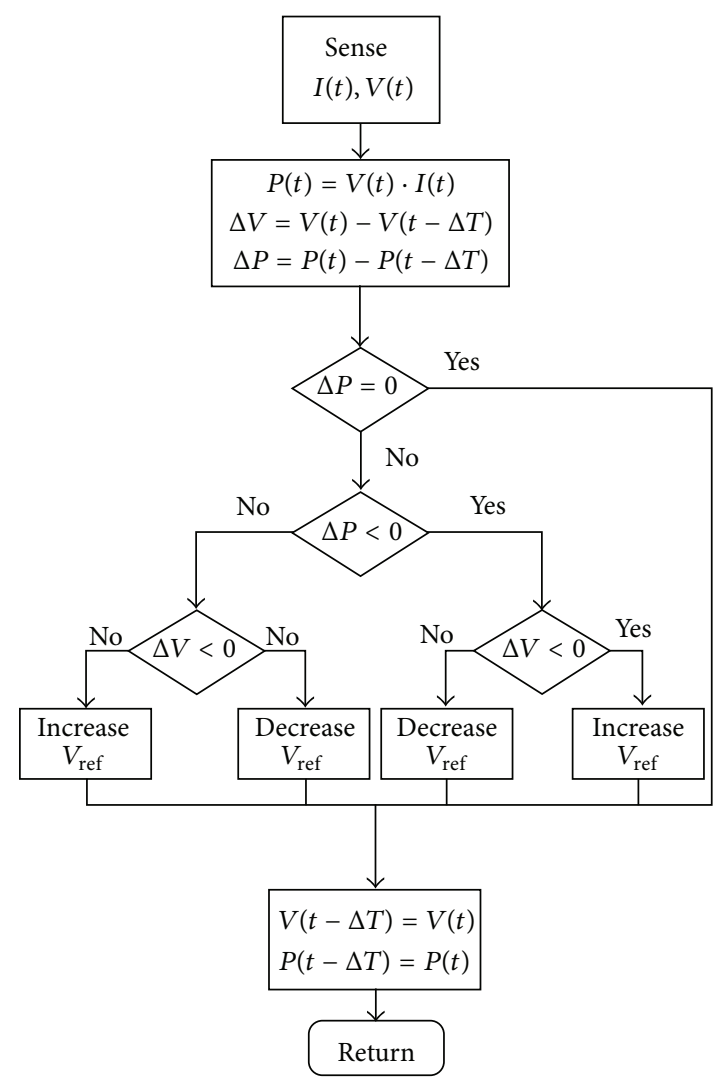

(a)

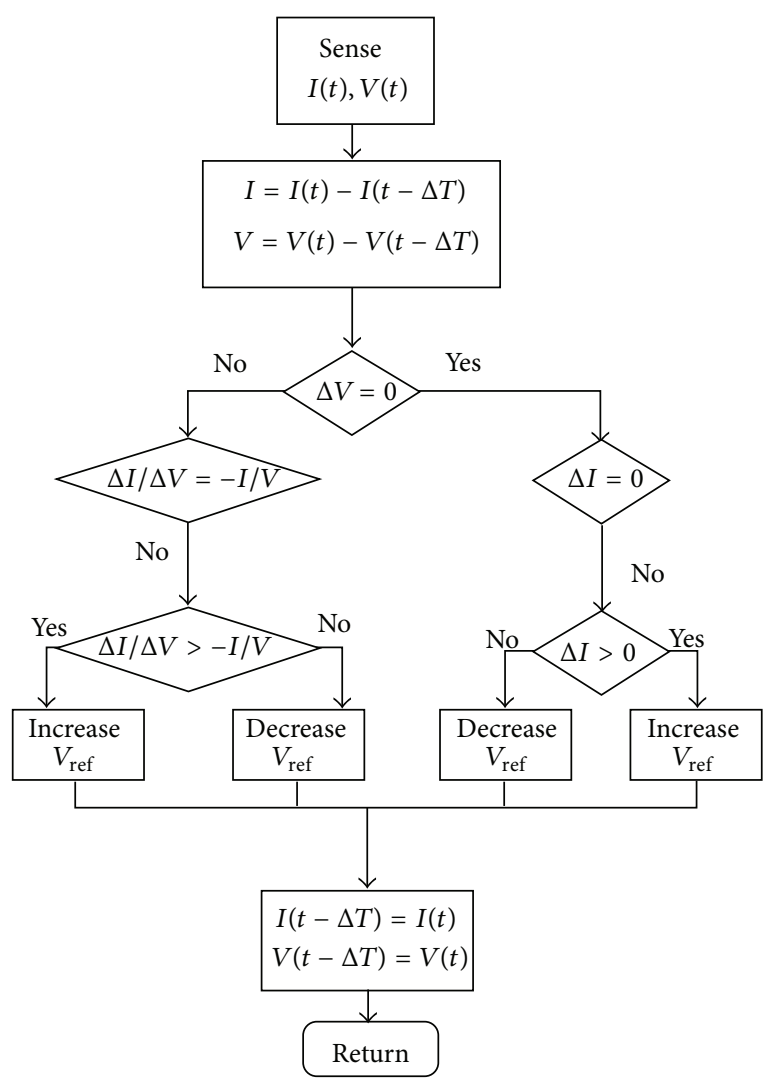

(b)

FIgURE 3: Flowchart representation of MPPT techniques: (a) P\&O and (b) IC.

with the reference voltage. This procedure results in an error signal applied to a pulse width modulator, which generates the duty cycle to drive a power electronic converter.

2.2.3. Perturb and Observe (P\&O). $\mathrm{P} \& \mathrm{O}$ is one the simplest MPPT methods $[27,28]$ with excellent performance and can be easily implemented in low cost systems. Some more sophisticated methods are based on the same principle employed in $\mathrm{P} \& \mathrm{O}$ method, for example, $\mathrm{HC}$ and modified HC [14].

The principle lies in disturbing the voltage or the current of the PV module and observing its effect on the resulting power. The algorithm compares the power of the previous step with that for the next step so that it can increase or decrease the voltage or current. This method changes the reference value, which can be a constant current or voltage. The operating point is then periodically moved towards the MPP by either increasing or decreasing the array voltage or current. The current is then modified at a constant rate, which represents a parameter that must be adjusted to obtain tradeoffs between fast dynamic response and reduced steadystate ripple.

The flowchart representation of $\mathrm{P} \& \mathrm{O}$ is given in Figure 3(a), which requires both voltage and current sensors. It is worth to mention that the performance can be improved by changing the step for the converter's duty cycle, so that tracking can be adjusted to better achieve MPP. When such step is variable, the method is called modified P\&O.

2.2.4. Incremental Conductance (IC). IC has been proposed as a solution to overcome some limitations of the $\mathrm{P} \& \mathrm{O}$ method, such as convergence speed and steady-state error [29]. Often cited as the best technique based on the principle of disturbance and observation, it aggregates some prominent advantages such as an easy and fast response to rapidly changing solar irradiances. In the IC method, the derivative (conductance) of the $P \times V$ curve is used by the algorithm, which is represented in Figure 3(b). The error is reduced because the operation point is less disturbed than in the $\mathrm{P} \& \mathrm{O}$ method. It is based on the fact that the derivative of power with respect to the voltage $V$ (IC) or current $I$ (incremental impedance-II) at the MPP is null.

Under such condition, the following expressions result:

$$
\begin{aligned}
& \frac{d P}{d V}=\frac{d(V \cdot I)}{d V}=I \cdot \frac{d V}{d V}+V \cdot \frac{d I}{d V}=I+V \cdot \frac{d I}{d V}, \\
& \frac{d P}{d I}=\frac{d(V \cdot I)}{d I}=I \cdot \frac{d V}{d I}+V \cdot \frac{d I}{d I}=V+I \cdot \frac{d V}{d I} .
\end{aligned}
$$

From the calculation of $\Delta V$ and $\Delta I$, and by using the values for $V$ and $I$, expressions (2) can be employed in 
TABLE 1: Comparison among constant voltage, $\mathrm{P} \& \mathrm{O}$, and incremental conductance MPPT control techniques.

\begin{tabular}{|c|c|c|}
\hline Method & Advantages & Disadvantages \\
\hline Fixed duty cycle & $\begin{array}{l}\text { (i) Inherent simplicity } \\
\text { (ii) Use of a pulse width modulator to drive the } \\
\text { dc-dc converter }\end{array}$ & (i) Low efficiency in terms of the extracted power \\
\hline Constant voltage & $\begin{array}{l}\text { (i) Easy implementation } \\
\text { (ii) Use of a single voltage sensor }\end{array}$ & $\begin{array}{l}\text { (i) Appreciable steady-state error due to the } \\
\text { difference between } V_{\mathrm{PV}} \text { and } V_{\mathrm{OC}}\end{array}$ \\
\hline Perturb and observe & (i) Operation close to the MPP & $\begin{array}{l}\text { (i) Relative complex implementation } \\
\text { (ii) Employment of two sensors (voltage and } \\
\text { current) } \\
\text { (iii) Need to choose between speed and accuracy }\end{array}$ \\
\hline Incremental conductance & $\begin{array}{l}\text { (i) Variable step } \\
\text { (ii) Fast and precise technique }\end{array}$ & $\begin{array}{l}\text { (i) Employment of two sensors (voltage and } \\
\text { current) } \\
\text { (ii) Complex implementation due to calculation } \\
\text { of derivatives }\end{array}$ \\
\hline
\end{tabular}

the algorithm decisions, thus comparing the instantaneous conductance $I / V$ and the incremental conductance, that is,

(i) $\Delta I / \Delta V=-I / V$ : the operating point lies exactly in the MPP;

(ii) $\Delta I / \Delta V>-I / V$ : the operating point lies to the left of the MPP;

(iii) $\Delta I / \Delta V<-I / V$ : the operating point lies to the right of the MPP.

Based on the results of the comparisons above, the algorithm takes the decision to increase or decrease the voltage across the PV array.

2.2.5. Brief Comparison among the Chosen Methods. The MPPT techniques analyzed in this work have been chosen considering reduced cost and wide applicability. It can be stated that constant voltage, $\mathrm{P} \& \mathrm{O}$, and IC are the best choices considering good cost-benefit ratio, while a fixed duty cycle is also analyzed only to demonstrate that it is not an effective approach if high efficiency is demanded. The aforementioned techniques are then compared in Table 1.

\section{Simulation Results}

Even though literature presents numerous examples that use the buck or boost converter to perform MPPT due to simplicity [22], the works developed by [30,31] effectively demonstrate that the accurate tracking of the MPP is only achieved when using buck-boost-type converters. In order to compare the performance of the analyzed techniques, a dc$\mathrm{dc}$ buck-boost converter operating in CCM is designed considering the operating conditions presented in Table 2 . The converter is responsible for performing MPPT when supplied by two parallel-connected strings, each one composed of five six-connected PV modules type KC200GT, whose ratings are shown in Table 3 [32]. According to Table 2, the power stage elements of the buck-boost converter can be designed as shown in Table 4.
TABLE 2: Design specifications of the buck-boost converter.

\begin{tabular}{lc}
\hline Parameter & Value \\
\hline Maximum power $\left(P_{\max }\right)$ & $2 \mathrm{~kW}$ \\
Output voltage $\left(V_{o}\right)$ & $100 \mathrm{~V}$ \\
Output voltage ripple $\left(\Delta V_{o}\right)$ & $5 \% V_{o}$ \\
Inductor current ripple $\left(\Delta I_{L}\right)$ & $5 \% I_{o}$ \\
Switching frequency $\left(f_{s}\right)$ & $70 \mathrm{kHz}$ \\
\hline
\end{tabular}

TABLE 3: Typical electric characteristics of PV module KC200GT (Kyocera, 2013) [32].

\begin{tabular}{lc}
\hline Parameter & Value \\
\hline Maximum power $\left(P_{\mathrm{PVmax}}\right)$ & $200 \mathrm{Wp}$ \\
Maximum power voltage $\left(V_{\mathrm{PVmax}}\right)$ & $26.3 \mathrm{~V}$ \\
Maximum power current $\left(I_{\mathrm{PVmax}}\right)$ & $7.61 \mathrm{~A}$ \\
Open circuit voltage $\left(V_{\mathrm{OC}}\right)$ & $32.9 \mathrm{~V}$ \\
Short circuit current $\left(I_{\mathrm{SC}}\right)$ & $8.21 \mathrm{~A}$ \\
Temperature coefficient of $V_{\mathrm{OC}}$ & $-1.23 \times 10^{-1} \mathrm{~V} /{ }^{\circ} \mathrm{C}$ \\
Temperature coefficient of $I_{\mathrm{SC}}$ & $3.18 \times 10^{-3} \mathrm{~A} /{ }^{\circ} \mathrm{C}$ \\
\hline
\end{tabular}

TABle 4: Power stage components for the designed buck-boost converter.

\begin{tabular}{lc}
\hline Parameter & Value \\
\hline Load resistance & $3.33 \Omega$ \\
Filter inductance & $1 \mathrm{mH}$ \\
Output filter capacitance & $37 \mu \mathrm{F}$ \\
Maximum voltages across the switch and the diode & $231.5 \mathrm{~V}$ \\
Average current through the switch & $22.8 \mathrm{~A}$ \\
Rms current through the switch & $34.7 \mathrm{~A}$ \\
Average current through the diode & $30 \mathrm{~A}$ \\
Rms current through the diode & $18 \mathrm{~A}$ \\
\hline
\end{tabular}

In order to verify the behavior of the MPPT techniques, irradiance and temperature vary according to the following profile, which has been defined arbitrarily: $800 \mathrm{~W} / \mathrm{m}^{2}-$ $32^{\circ} \mathrm{C} ; 1000 \mathrm{~W} / \mathrm{m}^{2}-32^{\circ} \mathrm{C} ; 700 \mathrm{~W} / \mathrm{m}^{2}-20^{\circ} \mathrm{C} ; 500 \mathrm{~W} / \mathrm{m}^{2}-25^{\circ} \mathrm{C}$; and $200 \mathrm{~W} / \mathrm{m}^{2}-32^{\circ} \mathrm{C}$. 

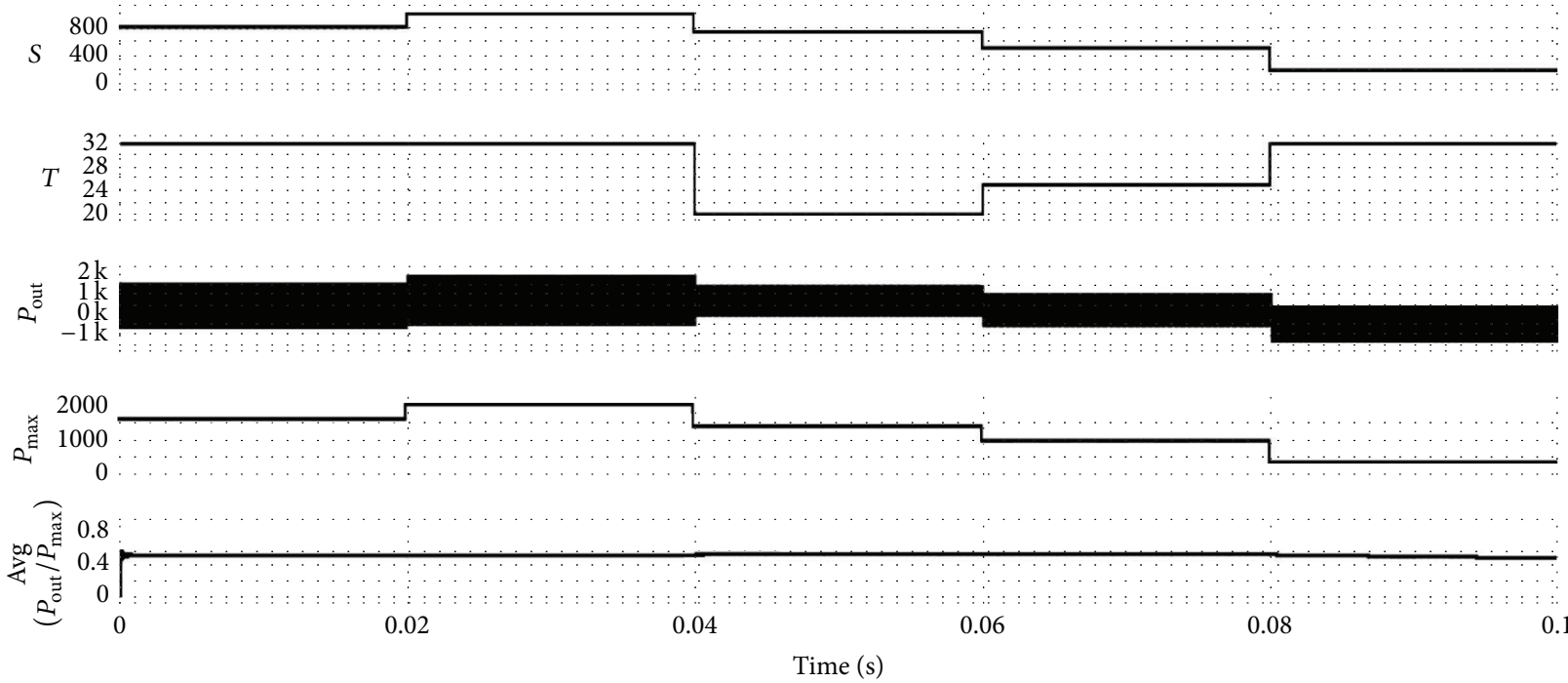

FiguRE 4: Irradiance profile $(S)$, temperature profile $(T)$, extracted power $\left(P_{\text {out }}\right)$, theoretical value of the maximum extracted power $\left(P_{\text {max }}\right)$, and average efficiency obtained with fixed duty cycle.

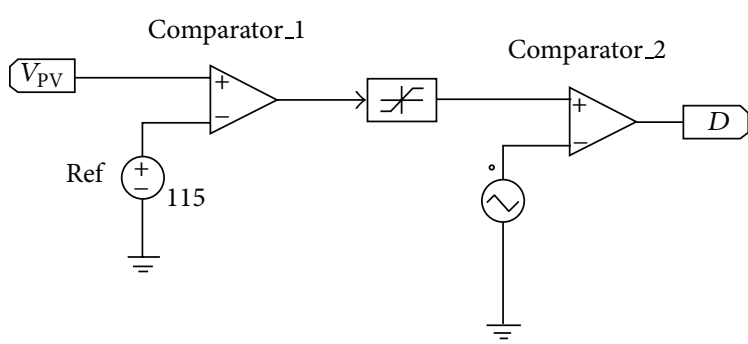

Figure 5: Implementation of CV technique.

By using software PSIM, the fixed duty cycle method has been implemented in order to demonstrate that low efficiency results when both irradiance and temperature vary. The curves are shown in Figure 4, where it is possible to notice that method is not recommended at high power levels due to reduced efficiency.

Figure 5 shows the CV method, which has inherent low cost and simplicity. It is worth to mention that this approach is widely used in regions that do not present abrupt irradiance variations. The main limitation of this technique is the presence of a steady-state error, which is the result of the difference between the open circuit voltage and the MPP voltage. In order to verify its performance in the aforementioned PV system, the average efficiency given by $P_{\text {out }} / P_{\max }$ is considered when both irradiation and temperature vary.

The waveforms of irradiance, temperature, extracted power, maximum theoretical power, and average efficiency of the system using CV are shown in Figure 6. It can be noticed that good performance is obtained if compared to the fixed duty cycle method. As the irradiance and temperature vary, the output power follows the maximum theoretical power, as it can be seen in Figure 6. The average efficiency of the PV system is somewhat high, that is, $94.46 \%$, as shown in Table 5, which considers the period between $0 \mathrm{~s}$ and $100 \mathrm{~ms}$.
TABLE 5: Efficiency obtained for the CV technique under distinct operating conditions.

\begin{tabular}{lccccc}
\hline Time interval $(\mathrm{ms})$ & $0-20$ & $20-40$ & $40-60$ & $60-80$ & $80-100$ \\
Temperature $\left({ }^{\circ} \mathrm{C}\right)$ & \multicolumn{2}{c}{32} & 20 & 25 & 32 \\
Irradiance $\left(\mathrm{W} / \mathrm{m}^{2}\right)$ & 800 & 1000 & 700 & 500 & 200 \\
Efficiency $(\%)$ & 94.49 & 95.16 & 94.45 & 93.78 & 94.42 \\
\hline
\end{tabular}

TABLE 6: Efficiency obtained for the $\mathrm{P} \& \mathrm{O}$ technique under distinct operating conditions.

\begin{tabular}{lccccc}
\hline Time $(\mathrm{ms})$ & $0-20$ & $20-40$ & $40-60$ & $60-80$ & $80-100$ \\
Temperature $\left({ }^{\circ} \mathrm{C}\right)$ & \multicolumn{2}{c}{32} & 20 & 25 & 32 \\
Irradiance $\left(\mathrm{W} / \mathrm{m}^{2}\right)$ & 800 & 1000 & 700 & 500 & 200 \\
Efficiency $(\%)$ & 96.66 & 97.35 & 98.02 & 98.4 & 97.45 \\
\hline
\end{tabular}

As it can be seen in Table 5, the results regarding the efficiency for the CV technique do not vary significantly considering that irradiance and temperature change in the simulation.

$\mathrm{P} \& \mathrm{O}$ is also a popular technique due to the easy implementation and high efficiency, whose representation is given in Figure 7. The main limitations are the presence of steadystate error, oscillations around the MPP in steady-state operation, slow dynamic response, and operation outside the MPP if the temperature and irradiance come to vary quickly. This technique presents improved efficiency if compared with CV.

In order to check the system performance, some waveforms are presented in Figure 8, which are the irradiance, temperature, extracted power, maximum theoretical power, and average efficiency of the system using P\&O. It can be seen that the performance achieved by $\mathrm{P} \& \mathrm{O}$ is improved than that of $\mathrm{CV}$ technique. As the irradiance and temperature vary, the output power follows the maximum theoretical power profile more closely. It means that the average efficiency of the PV system is higher, that is, $97.58 \%$, as it can be noticed in Table 6 . 


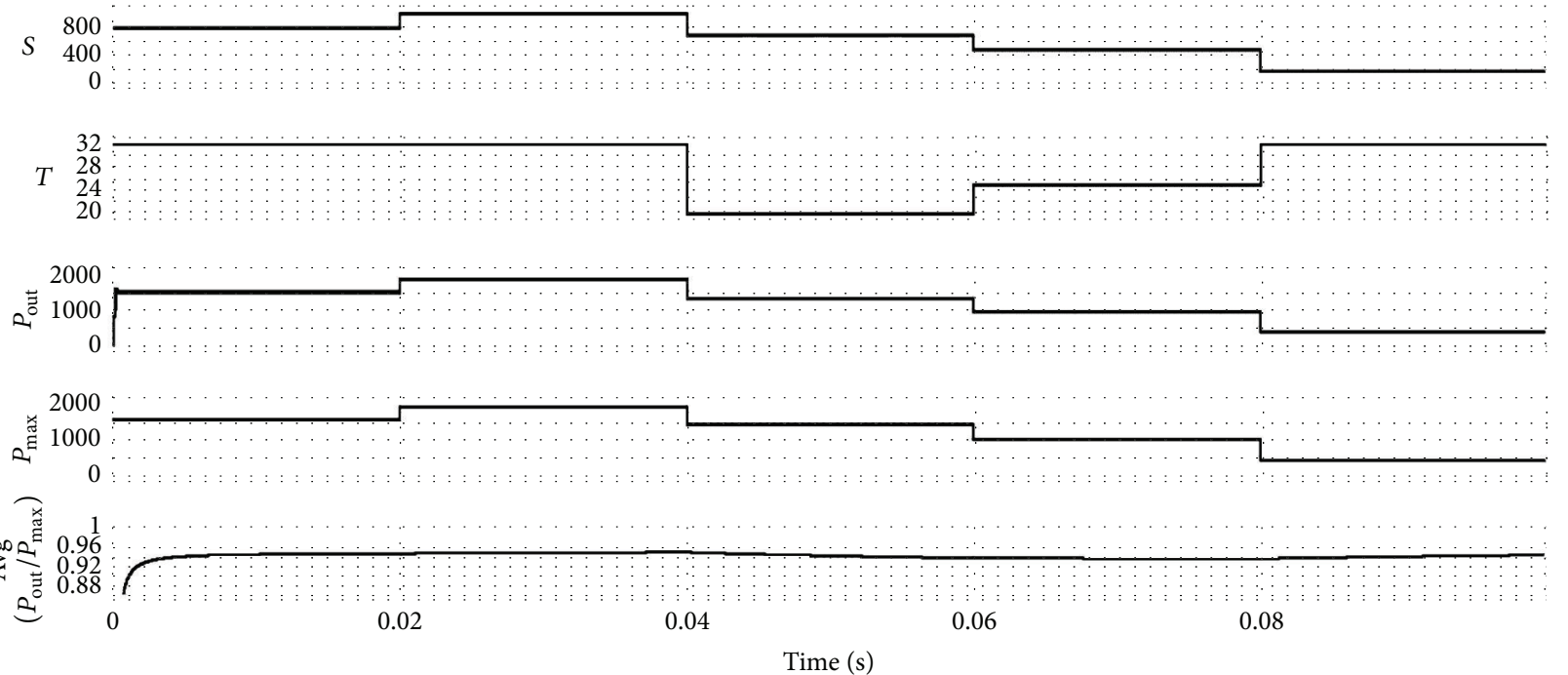

Figure 6: Irradiance profile $(S)$, temperature profile $(T)$, extracted power $\left(P_{\text {out }}\right)$, theoretical value of the maximum extracted power $\left(P_{\text {max }}\right)$, and average efficiency obtained with CV technique.

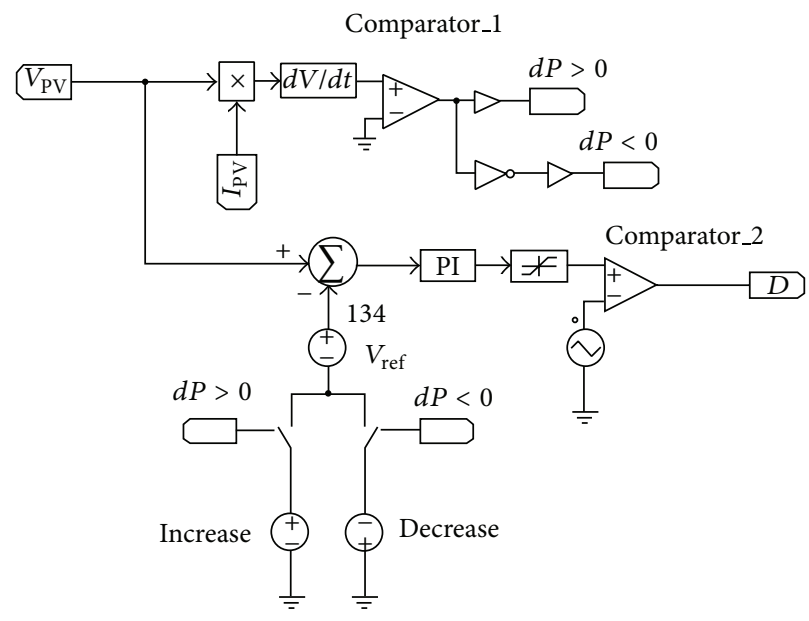

FIGURE 7: Implementation of $\mathrm{P} \& \mathrm{O}$ technique.

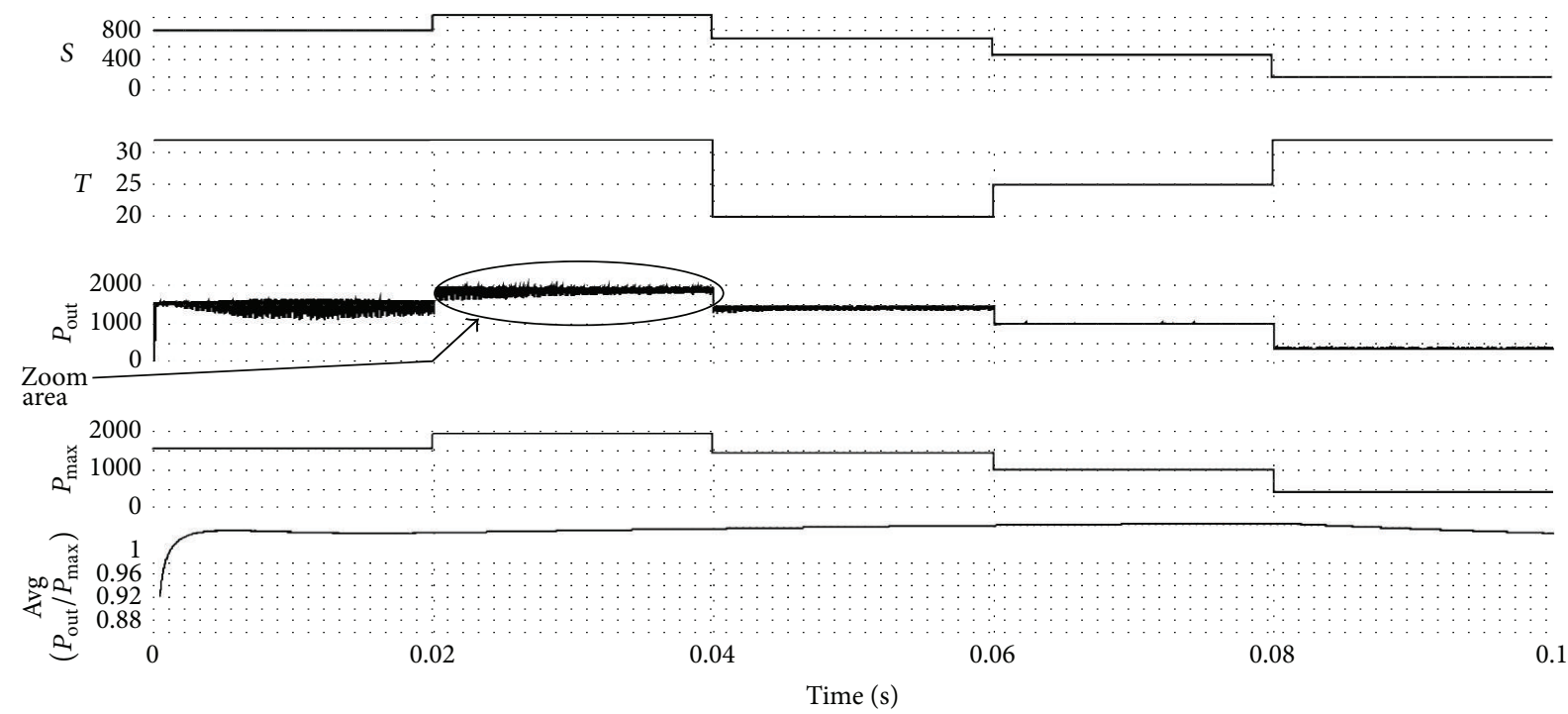

FIGURE 8: Irradiance profile $(S)$, temperature profile $(T)$, extracted power $\left(P_{\text {out }}\right)$, theoretical value of the maximum extracted power $\left(P_{\text {max }}\right)$, and average efficiency obtained with $\mathrm{P} \& \mathrm{O}$ technique. 


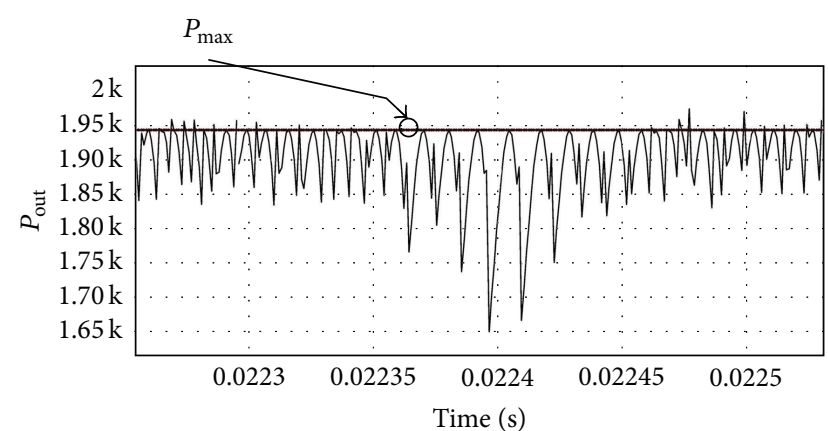

Figure 9: Detailed view of $P_{\text {out }}$ and $P_{\max }$ when using P\&O.

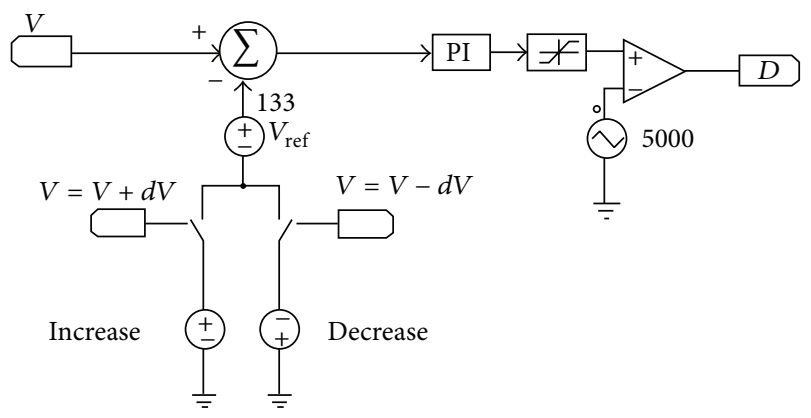

FIgURE 10: Implementation of IC technique.

According to Table 6, efficiency for the $\mathrm{P} \& \mathrm{O}$ technique varies when distinct irradiance and temperature levels are used unlike in CV technique. It can be noticed that the efficiency increases as the irradiance does while keeping the temperature constant at $32^{\circ} \mathrm{C}$. However, efficiency tends to decrease as the operation temperature increases.

Figure 9 presents the detailed view of $P_{\text {out }}$ and $P_{\max }$, where it can be seen that the extracted power oscillates around the MPP significantly, which is a significant drawback of $\mathrm{P} \& \mathrm{O}$.

Considering that IC is supposed to overcome the limitations of $\mathrm{P} \& \mathrm{O}$ technique regarding convergence speed and steady-state error, it is worth to compare its performance with those regarding the aforementioned techniques. IC can be implemented in PSIM according to the circuit shown in Figure 10.

In order to check the system performance, the irradiance, temperature, extracted power, maximum theoretical power, and average efficiency waveforms of the system using IC are shown in Figure 11. Once again, performance is significantly improved considering all the aforementioned techniques as expected. As the irradiance and temperature vary, the output power follows the maximum theoretical power profile very closely and the highest value of the average efficiency is obtained in this case, that is, $98.53 \%$, as it can be noticed in Table 7.

According to Table 7, the results regarding the efficiency for the IC technique depend strictly on irradiance and
TABLE 7: Efficiency obtained for the IC technique under distinct operating conditions.

\begin{tabular}{lccccc}
\hline Time $(\mathrm{ms})$ & $0-20$ & $20-40$ & $40-60$ & $60-80$ & $80-100$ \\
Temperature $\left({ }^{\circ} \mathrm{C}\right)$ & \multicolumn{2}{c}{32} & 20 & 25 & 32 \\
Irradiance $\left(\mathrm{W} / \mathrm{m}^{2}\right)$ & 800 & 1000 & 700 & 500 & 200 \\
Efficiency $(\%)$ & 98.42 & 98.66 & 98.87 & 99.11 & 97.59 \\
\hline
\end{tabular}

TABLE 8: Comparison of the global average efficiency for the MPPT techniques.

\begin{tabular}{lc}
\hline Technique & Average efficiency $\left(P_{\text {out }} / P_{\max }\right)$ \\
\hline Fixed duty cycle & $57.80 \%$ \\
CV & $94.46 \%$ \\
P\&O & $97.58 \%$ \\
IC & $98.53 \%$ \\
\hline
\end{tabular}

temperature levels. If the temperature remains constant, efficiency does not vary significantly as irradiance increases. On the other hand, efficiency tends to decrease as the operating temperature increases, especially at low irradiance levels as it occurs for $S=200 \mathrm{~W} / \mathrm{m}^{2}$ and $T=32^{\circ} \mathrm{C}$.

Finally, the average efficiency of the MPPT techniques can be properly compared. According to Table 8, IC has the best average efficiency within the analyzed approaches.

\section{Conclusion}

This work has analyzed four MPPT methods that allow extracting the maximum power from PV modules. The paper investigates the performance of popular MPPT techniques (i.e., $\mathrm{CV}, \mathrm{P} \& \mathrm{O}$, and IC), while simulation results considering the maximum power extracted from a PV array have also been obtained.

From the individual analysis of each technique, it can be stated that $\mathrm{CV}$ uses only one voltage sensor associated with easy implementation, but efficiency is poor. $\mathrm{P} \& \mathrm{O}$ presents the advantage of operating close to the MPP, independent of temperature and irradiance variations, although it uses two sensors. Besides, tradeoffs must be made between speed and efficiency. IC uses variable step to achieve high speed and low steady-state error of calculation of the derivative of the current with respect to the voltage. Its disadvantages lie in the use of two sensors associated with complex implementation, although it presents high performance.

Finally, the performance of the MPPT techniques has been analyzed by using a dc-dc buck converter supplying a resistive load. It can be seen that the obtained results do not imply significant error regarding the operation in MPP condition. In terms of efficiency, the analyzed methods present good performance if compared with the fixed duty cycle method, which is not adequate for high power PV 

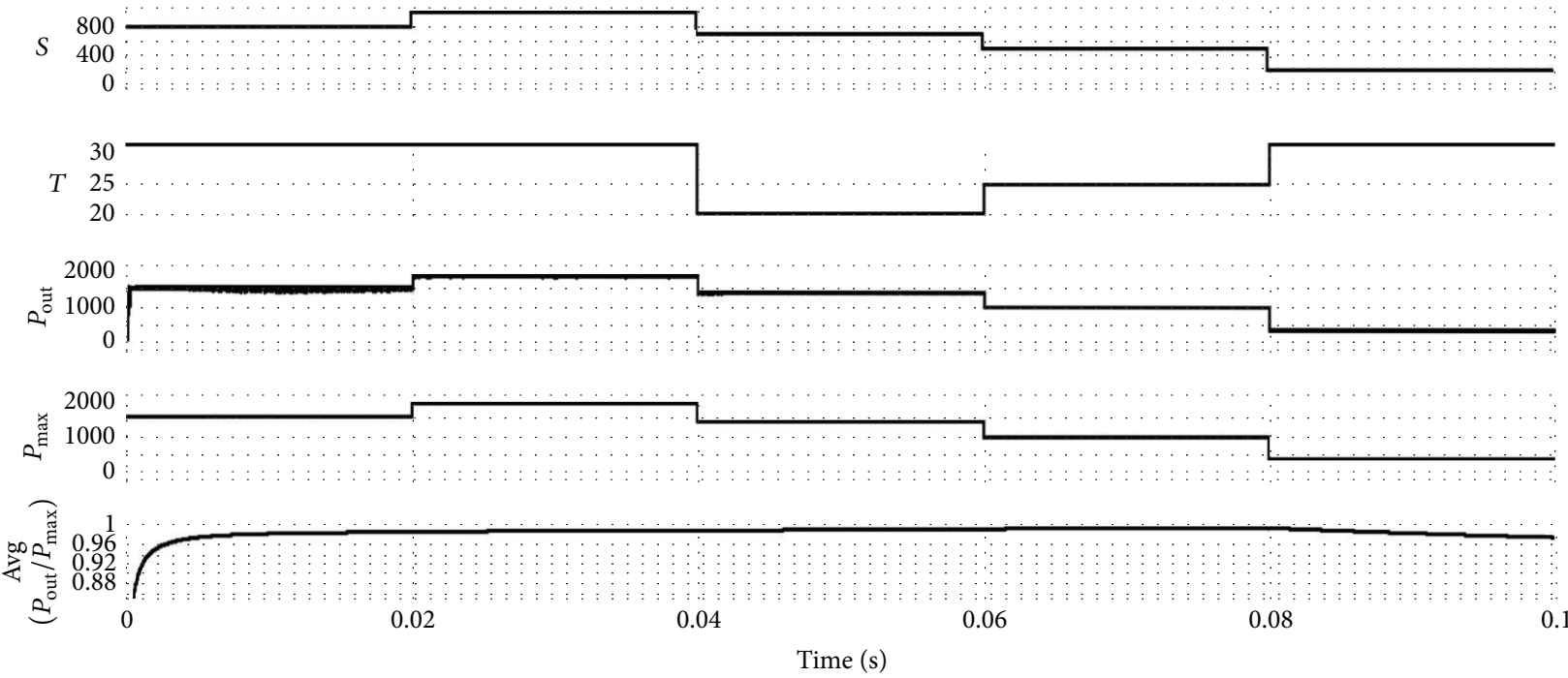

FigURE 11: Irradiance profile $(S)$, temperature profile $(T)$, extracted power $\left(P_{\text {out }}\right)$, theoretical value of the maximum extracted power $\left(P_{\text {max }}\right)$, and average efficiency obtained with IC technique.

systems. IC algorithm has proven to be the best one, mainly because a significant increase in the extracted power exists.

\section{Conflict of Interests}

The authors declare that there is no conflict of interests regarding the publication of this paper.

\section{Acknowledgments}

The authors acknowledge CAPES, FAPEMIG, CNPq, and INERGE for the support to this work.

\section{References}

[1] B. L. A. da Silva, J.-M. S. Lafay, F. L. Tofoli, and L. S. Scartazzini, "Case study: Hydroelectric generation employing the water distribution network in Pato Branco, Brazil," in Proceedings of the 10th IASTED International Conference on Power and Energy Systems (EUROPES '11), pp. 50-54, June 2011.

[2] J. T. Bialasiewicz, "Renewable energy systems with photovoltaic power generators: operation and modeling," IEEE Transactions on Industrial Electronics, vol. 55, no. 7, pp. 2752-2758, 2008.

[3] P. G. Barbosa, H. A. C. Braga, M. D. C. B. Rodrigues, and E. C. Teixeira, "Boost current multilevel inverter and Its application on single-phase grid-connected photovoltaic systems," IEEE Transactions on Power Electronics, vol. 21, no. 4, pp. 1116-1124, 2006.

[4] S. Lee, J.-E. Kim, and H. Cha, "Design and implementation of photovoltaic power conditioning system using a currentbased maximum power point tracking," Journal of Electrical Engineering \& Technology, vol. 5, no. 4, pp. 606-613, 2010.

[5] J.-M. Kwon, K.-H. Nam, and B.-H. Kwon, "Photovoltaic power conditioning system with line connection," IEEE Transactions on Industrial Electronics, vol. 53, no. 4, pp. 1048-1054, 2006.

[6] J. H. R. Enslin and D. B. Snyman, "Simplified feed-forward control of the maximum power point in PV installations," in Proceedings of the International Conference on Industrial Electronics, Control, Instrumentation, and Automation, pp. 548553, San Diego, Calif, USA, 1992.

[7] C. R. Sullivan and M. J. Powers, "High-efficiency maximum power point tracker for photovoltaic arrays in a solar-powered race vehicle," in Proceedings of the IEEE 24th Annual Power Electronics Specialist Conference, pp. 574-580, June 1993.

[8] C. Hua and C. Shen, "Control of DC/DC converters for solar energy system with maximum power tracking," in Proceedings of the 23rd Annual International Conference on Industrial Electronics, Control, and Instrumentation (IECON '97), pp. 827832, November 1997.

[9] H. E.-S. A. Ibrahim, F. F. Houssiny, H. M. Zein El-Din, and M. A. El-Shibini, "Microcomputer controlled buck regulator for maximum power point tracker for dc pumping system operates from photovoltaic system," in Proceedings of the IEEE International Fuzzy Systems Conference, pp. 406-411, August 1999.

[10] C. Adnene and J. Moncef, "Modelling and simulation of a PVinverter-asychronous motor association in photovoltaic pumping systems," in Proceedings of the Large Engineering Systems Conference on Power Engineering (LESCOPE '01), pp. 146-151, Halifax, Canada.

[11] D. Hohm and M. Ropp, "Comparative study of maximum power point tracking algorithms using an experimental, programmable, maximum power point tracking test bed," in Proceedings of the 28th IEEE Photovoltaic Specialists Conference, pp. 1699-1702, IEEE, Anchorage, Alaska, USA, 2000.

[12] Y.-T. Hsiao and C.-H. Chen, "Maximum power tracking for photovoltaic power system," in Proceedings of the 37th IAS Annual Meeting and World Conference on Industrial Applications of Electrical Energy, pp. 1035-1040, October 2002.

[13] Y. Huang, M. Shen, F. Z. Peng, and J. Wang, "A Z-source inverter for residential photovoltaic systems," IEEE Transactions on Power Electronics, vol. 21, no. 6, pp. 1776-1782, 2006.

[14] T. Esram and P. L. Chapman, "Comparison of photovoltaic array maximum power point tracking techniques," IEEE Transactions on Energy Conversion, vol. 22, no. 2, pp. 439-449, 2007. 
[15] A. H. M. Nordin and A. M. Omar, "Modeling and simulation of photovoltaic (PV) array and maximum power point tracker (MPPT) for grid-connected PV system," in Proceedings of the 3rd International Symposium and Exhibition in Sustainable Energy and Environment (ISESEE '11), pp. 114-119, June 2011.

[16] B. I. Rani, G. S. Ilango, and C. Nagamani, "Enhanced power generation from PV array under partial shading conditions by shade dispersion using $\mathrm{Su} \mathrm{Do} \mathrm{Ku}$ configuration," IEEE Transactions on Sustainable Energy, vol. 4, no. 3, pp. 594-601, 2013.

[17] E. Koutroulis and F. Blaabjerg, "A new technique for tracking the global maximum power point of PV arrays operating under partial-shading conditions," IEEE Journal of Photovoltaics, vol. 2, no. 2, pp. 184-190, 2012.

[18] M. A. Fakhfakh, N. M. S. Alotaibi, and M. S. Bouhlel, "Control technique for a photovoltaic system with a Power grid connection," in Proceedings of the International Conference on Green Energy, pp. 60-64, Sfax, Tunisia, March 2014.

[19] H. S. Sahu, S. Roy, and S. K. Nayak, "Estimation of maximum power point of PV array using datasheet values for microgrid integration," in Proceedings of the IEEE Innovative Smart Grid Technologies-Asia (ISGT ASIA '14), pp. 754-759, Kuala Lumpur, Malaysia, May 2014.

[20] M. Veerachary, T. Senjyu, and K. Uezato, "Maximum power point tracking of coupled inductor interleaved boost converter supplied PV system," IEE Proceedings: Electric Power Applications, vol. 150, no. 1, pp. 71-80, 2003.

[21] R. L. Carletti, L. C. G. Lopes, and P. G. Barbosa, "Active and reactive power control scheme for a grid-connected photovoltaic generation system based on VSI with selective harmonic elimination," in Proceedings of the 8th Brazilian Power Electronics Conference, pp. 1-8, 2005.

[22] M. G. Villalva and E. Ruppert F, "Analysis and simulation of the P\&amp;O MPPT algorithm using a linearized PV array model," in Proceedings of the 35th Annual Conference of the IEEE Industrial Electronics Society (IECON '09), pp. 231-236, November 2009.

[23] M. G. Villalva, T. G. De Siqueira, and E. Ruppert Filho, "Voltage regulation of photovoltaic arrays: small-signal analysis and control design," IET Power Electronics, vol. 3, no. 6, pp. 869-880, 2010.

[24] W. Xiao, P. R. Palmer, A. Capel, and W. G. Dunford, "Regulation of photovoltaic voltage," IEEE Transactions on Industrial Electronics, vol. 54, no. 3, pp. 1365-1374, 2007.

[25] W. Xiao, N. Ozog, and W. G. Dunford, "Topology study of photovoltaic interface for maximum power point tracking," IEEE Transactions on Industrial Electronics, vol. 54, no. 3, pp. 1696-1704, 2007.

[26] M. A. S. Masoum, H. Dehbonei, and E. F. Fuchs, “Theoretical and experimental analyses of photovoltaic systems with voltage- and current-based maximum power-point tracking," IEEE Transactions on Energy Conversion, vol. 17, no. 4, pp. 514522, 2002.

[27] N. Femia, G. Petrone, G. Spagnuolo, and M. Vitelli, "Optimizing duty-cycle perturbation of P\&O MPPT technique," in Proceedings of the IEEE 35th Annual Power Electronics Specialists Conference (PESC '04), vol. 3, pp. 1939-1944, June 2004.

[28] N. Femia, M. Fortunato, G. Lisi, G. Petrone, G. Spagnuolo, and M. Vitelli, "Guidelines for the optimization of the P\&amp;O technique in grid-connected double-stage photovoltaic systems," in Proceedings of the IEEE International Symposium on Industrial Electronics (ISIE '07), pp. 2420-2425, June 2007.
[29] K. H. Hussein, I. Muta, T. Hoshino, and M. Osakada, "Maximum photovoltaic power tracking: an algorithm for rapidly changing atmospheric conditions," IEE Proceedings: Generation, Transmission and Distribution, vol. 142, no. 1, pp. 59-64, 1995.

[30] E. D. Aranda, J. A. G. Galán, C. S. Cardona, and J. M. A. Marques, "Measuring the I-V curve of PV generator," IEEE Industrial Electronics Magazine, vol. 3, no. 3, pp. 4-14, 2009.

[31] R. F. Coelho, F. M. Concer, and D. C. Martins, "A proposed photovoltaic module and array mathematical modeling destined to simulation," in Proceedings of the IEEE International Symposium on Industrial Electronics (ISIE '09), pp. 1624-1629, July 2009.

[32] Kyocera, KC200GT-High Efficiency Multicrystal Photovoltaic Module, 2013, http://www.kyocerasolar.com/assets/001/5195.pdf. 

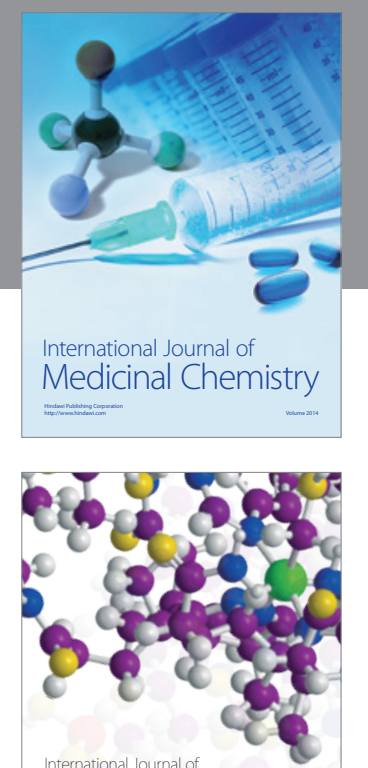

\section{Carbohydrate} Chemistry

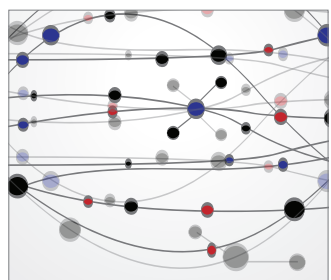

The Scientific World Journal
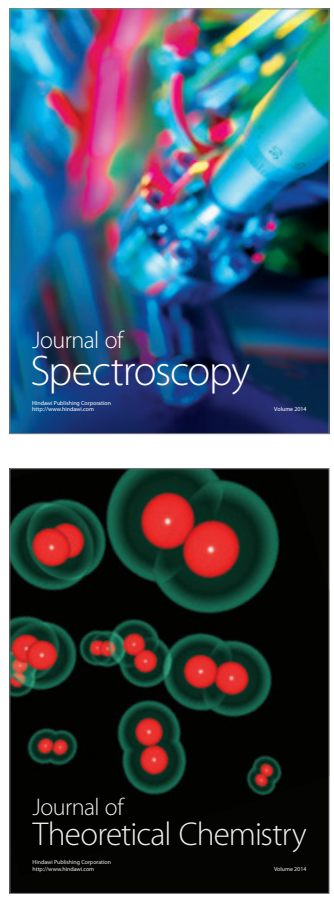
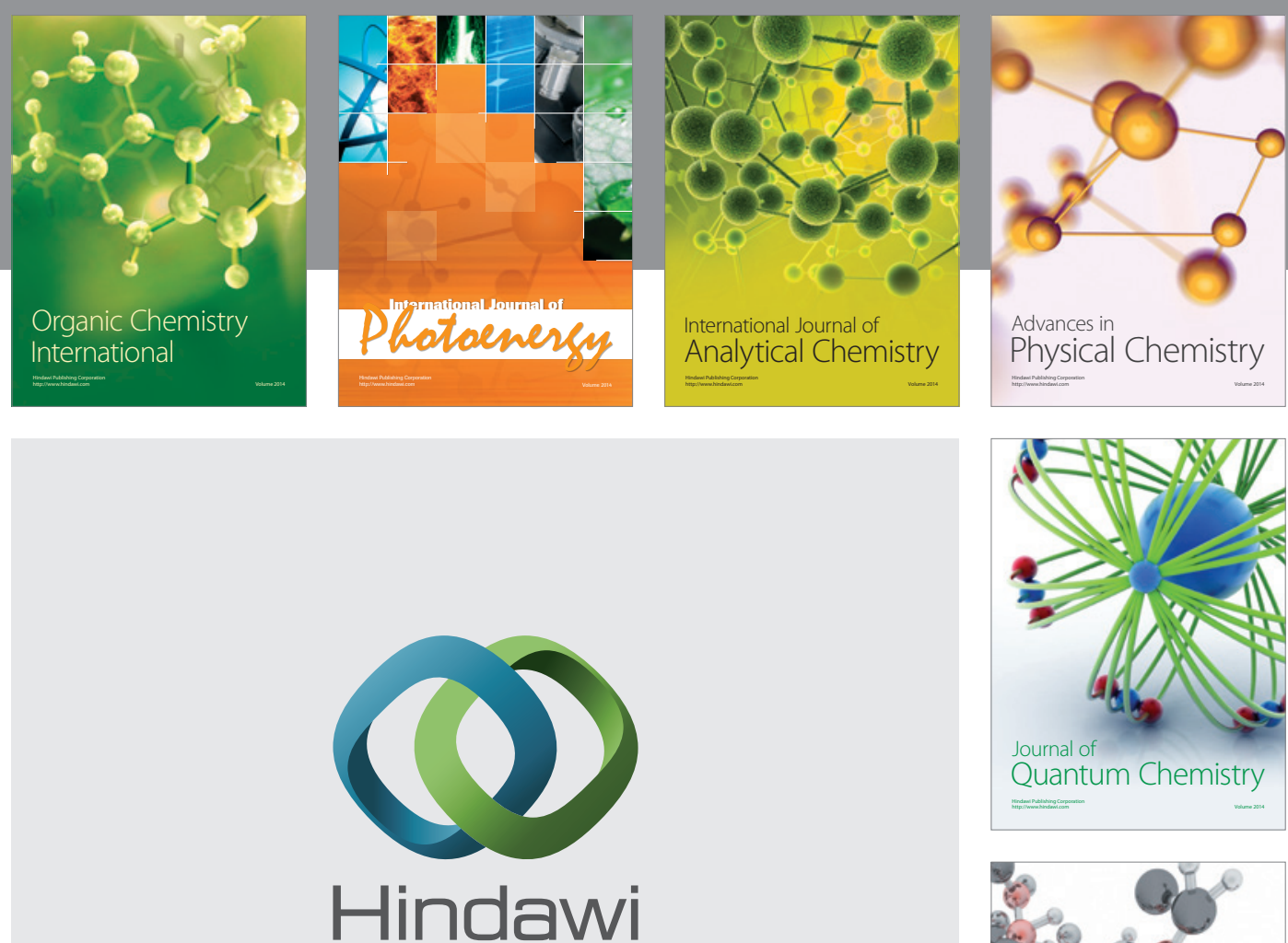

Submit your manuscripts at

http://www.hindawi.com

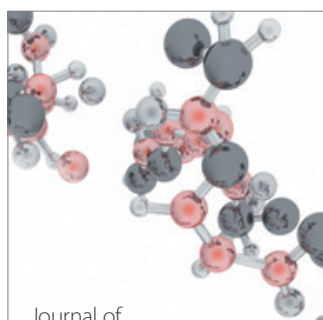

Analytical Methods

in Chemistry

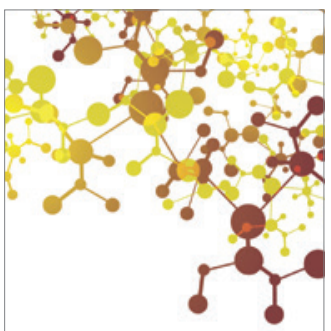

Journal of

Applied Chemistry

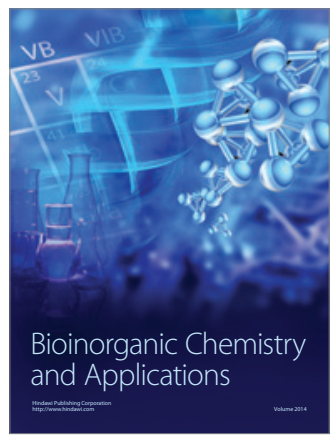

Inorganic Chemistry
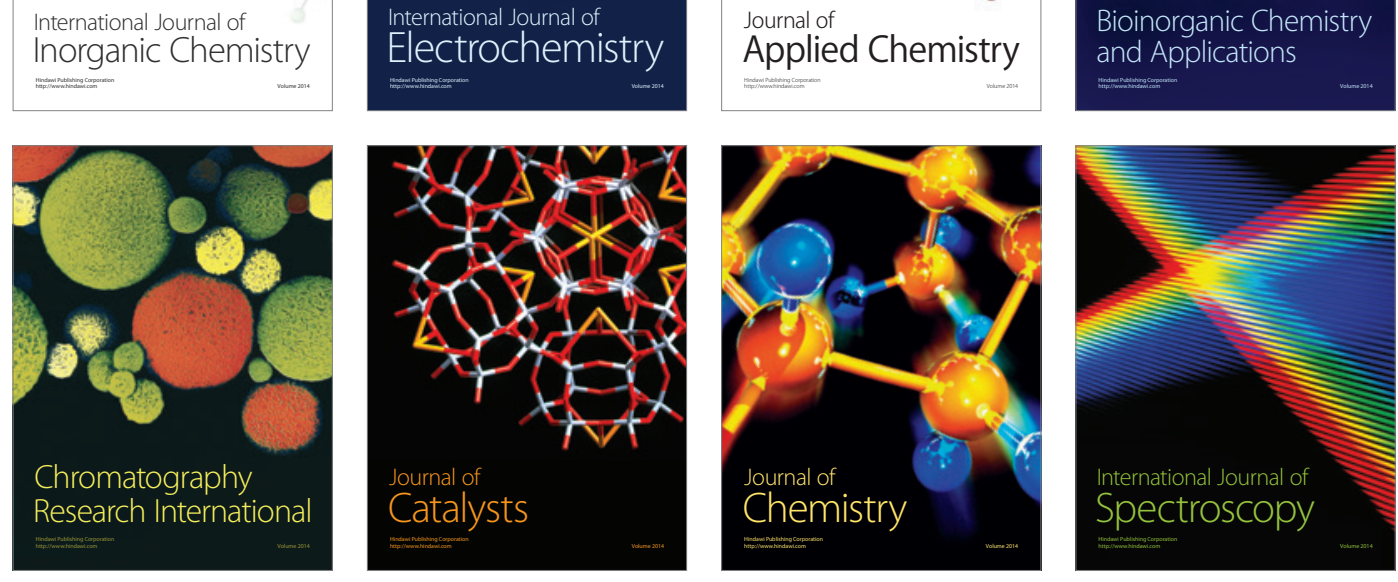